\title{
Non-compact cardiomyopathia, avagy a baljós trabekuláltság
}

\author{
Kurczina Anita', Kracskó Bertalan', Balogh László', Rácz Ágnes', \\ Vágó Hajnalka², Clemens Marcell', Csanádi Zoltán', Borbély Attila'
}

\author{
1Debreceni Egyetem, Klinikai Központ, Kardiológiai és Szívsebészeti Klinika, Debrecen \\ ${ }^{2}$ Semmelweis Egyetem, Városmajori Szív- és Érgyógyászati Klinika, Budapest
}

Levelezési cím:

Dr. Kurczina Anita, Debreceni Egyetem, Klinikai Központ, Kardiológiai és Szívsebészeti Klinika

4031 Debrecen, Móricz Zsigmond krt. 22., e-mail: anita.kurczina@gmail.com

A 32 éves férfi beteget 2018 októberében súlyos (NYHA III-IV.) szívelégtelenség (SzE) tünetek miatt hospitalizáltuk. Echokardiográfia nagymértékben tágult szívüregeket, jelentősen csökkent szisztolés balkamra-funkciót (ejekciós frakció, EF 18\%) és súlyos funkcionális mitralis regurgitációt mutatott. Non-compact cardiomyopathia (NCCMP) merült fel, amelyet szív MR-vizsgálat megerősített. K-vitamin-antagonistát indítottunk. Az SzE bázisterápia lassú feltitrálása mellett a beteg funkcionális állapota fokozatosan javult. A beteget hordozható cardioverter defibrillátorral (WCD) bocsátottuk otthonába. Kontrollvizsgálatok során a beteg terhelhetőségének további, jelentős javulásáról számolt be (NYHA I-II. funkcionális stádium), a bázisterápia optimalizálása mellett a szisztolés balkamra-funkció (EF 30\%) növekedését észleltük, a bal kamrai dimenziók azonban érdemben nem változtak. Mindezek alapján három hónap elteltével beültethető cardioverter defibrillátor (ICD) implantációja (primer prevenció) mellett döntöttünk. Szívtranszplantáció irányú továbblépést a funkcionális állapot romlása vagy terápiarefrakter kamrai ritmuszavar fellépése esetén tervezünk.

Az NCCMP morfológiai sajátossága az abnormális trabekulákat tartalmazó, szivacsos megjelenésű kamrai szívizomzat (compact és a non-compact réteg), amely leginkább a bal kamra csúcsát érinti. Etiológiáját tekintve továbbra is kérdéses, hogy az NCCMP különálló entitás-e, vagy más szívbetegség fenotípusos megjelenése. Súlyos szívelégtelenség, hirtelen szívhalál, tromboembóliás események társulhatnak hozzá. Diagnosztikája képalkotó eljárásokon (TTE/TEE/MR) alapszik.

Kulcsszavak: non-compact cardiomyopathia, szívelégtelenség, kardiológiai képalkotó eljárások, implantálható cardioverter defibrillátor

\section{Non-compact cardiomyopathy or ominous trabeculation}

The 32-year-old male patient was hospitalized because of severe (NYHA class III-IV) heart failure (HF) symptoms in October 2018. Transthoracic echocardiography (TTE) showed extremely enlarged heart chambers, largely depressed left ventricular (LV) systolic function (ejection fraction, EF 18\%) and severe functional mitral regurgitation. Cardiac MRI confirmed the suspected non-compact cardiomyopathy (NCCMP). Vitamin K antagonist was started. Next to the slow up-titration of the evidence-based HF therapy, a continuous improvement in the patient's functional status could be observed. The patient was discharged with a wearable cardioverter defibrillator (WCD). Next to the optimized drug therapy echocardiography revealed a significant improvement in the EF (30\%) during follow-up, however, LV dimensions remained unchanged. Based on the results, placement of an implantable cardioverter defibrillator (ICD) for primary prevention was performed. Heart transplantation will be considered in case of worsening in the functional status or by occurrence of therapy refractory ventricular arrhythmias.

The morphological feature of NCCMP is a spongy ventricular myocardium with abnormal trabeculation (compact and non-compact myocardial layers) usually most evident in the left ventricular apex. However, etiology of NCCMP is still uncertain: it remains unclear, whether it is a separate entity or a phenotypic appearance of other cardiac diseases. Its clinical presentation may occur with severe HF, sudden cardiac death or thromboembolic events. The diagnosis of NCCMP is based on cardiac imaging (TTE/TEE/MR).

Keywords: non-compact cardiomyopathy, heart failure, cardiac imaging, implantable cardioverter defibrillator 


\section{Esetismertetés}

Egy 32 éves férfi betegünk anamnézisében nagyobb megbetegedés nem szerepelt, gyógyszert rendszeresen nem szedett. 2018 októberében hasi puffadás, heves szívdobogásérzés, gyengeség, szédülés miatt OMSZ szállította a Sürgősségi Klinika Ambulanciájára. Fizikális vizsgálat során mindkét tüdő felett apróhólyagú nedves szörtyzörejek és hasi nyomásérzékenység volt észlelhető. EKG-n bal anterior hemiblokk és bal kamrai strain jelek ábrázolódtak (1. ábra). Laborokban kissé emelkedett D-dimert (1,09 mg FEU/I) és májenzimeket (GPT $70 \mathrm{U} / \mathrm{l}$, totál bilirubin $53 \mu \mathrm{mol} / \mathrm{l}$ ) mértek. Hasi ultrahangvizsgálat során kis mennyiségü ascites került leírásra. Az elvégzett mellkas CT tüdőembóliát kizárt, azonban jobb oldali hydrothorax, cardiomegália és kisvérköri pangás igazolódott. Kardiológiai konzílium során végzett echokardiográfia során igen tág szívüregek, súlyos fokú funkcionális mitralis regurgitáció, jelentősen

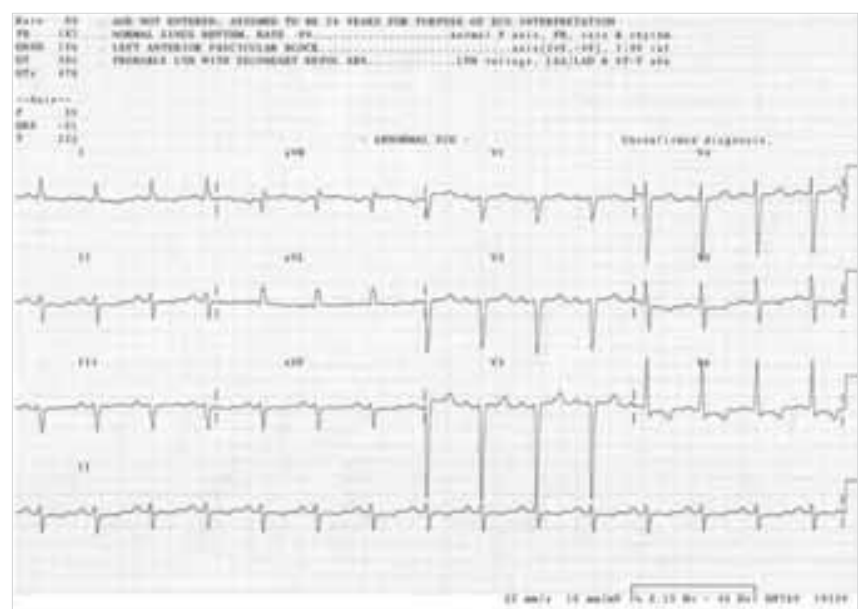

1. ÁBRA. A 32 éves férfi beteg 12 elvezetéses EKG-felvétele: 89/min frekvenciájú sinusritmus, bal tengelyállás, norm. AV-idő, keskeny QRS, balkamra-hipertrófia és bal kamrai strain jelek, BAH csökkent szisztolés balkamra-funkció (ejekciós frakció, EF 18-20\%), diffúz hypokinesis, restriktív mitralis beáramlási görbe, emelkedett számított szisztémás vaszkuláris rezisztencia és jobb kamrai nyomás ábrázolódott. A bal kamra csúcsánál és a laterális fal mediális és csúcsi részénél észlelt fokozottabb trabekularizáció felvetette non-compactatio lehetőségét (2. ábra).

A beteg panaszai, vizsgálati eredményei alapján, az újonnan felismert cardiomyopathia miatt a Belgyógyászati Intenzív Osztályra került felvételre. Intravénás, majd per os kacsdiuretikum, valamint a szívelégtelenség bázisterápia elkezdését követően klinikai állapota lassan javult. További kivizsgálás céljából a beteg klinikánkra került átvételre. Felvételkor 6 perces sétateszt alkalmával már 500 m-t teljesített. Laborokban magas NT-proBNP-érték (2436 ng/l), vírusszerológia során átvészelt EBV-fertőzés igazolódott, endokrin és autoimmun vizsgálatok eredményei negatívak voltak. Genetikai elemzésre vérmintát vettünk (eredmény folyamatban). A cardiomyopathia etiológiájának tisztázása céljából szív-MR történt, amely csúcsi harmadban laterális dominanciával és a csúcsban fokozott trabekularizáció alapján megerősítette a non-compact cardiomyopathia (NCCMP) diagnózisát. A vizsgálat során súlyosan csökkent bal kamrai $E F$, kifejezett diffúz bal kamrai hypokinesis, extrém mértékben emelkedett bal kamrai végdiasztolés és végszisztolés volumenek, sphericusan remodellált bal kamra, megtartott verővolumen, normál bal kamrai izomtömeg került leírásra. Zsírelnyomásos (SPIR: spectral inversion recovery) felvételeken miokardiális ödémára utaló jelintenzitás-fokozódás nem ábrázolódott, kontrasztanyag beadását követően körülírt késői típusú kontraszthalmozás a szívizomzatban, illetve a pericardiumban nem alakult ki. Az MR-kép akut myocarditisre nem utalt (3. ábra és 1. táblázat).

Hipotóniahajlam miatt a szívelégtelenség bázisterápia (ramipril, carvedilol, spironolakton) és adjuváns kezelés (dihydralazin, ISMN, trimetazidin, koenzim- $Q_{10}$ ) lassú
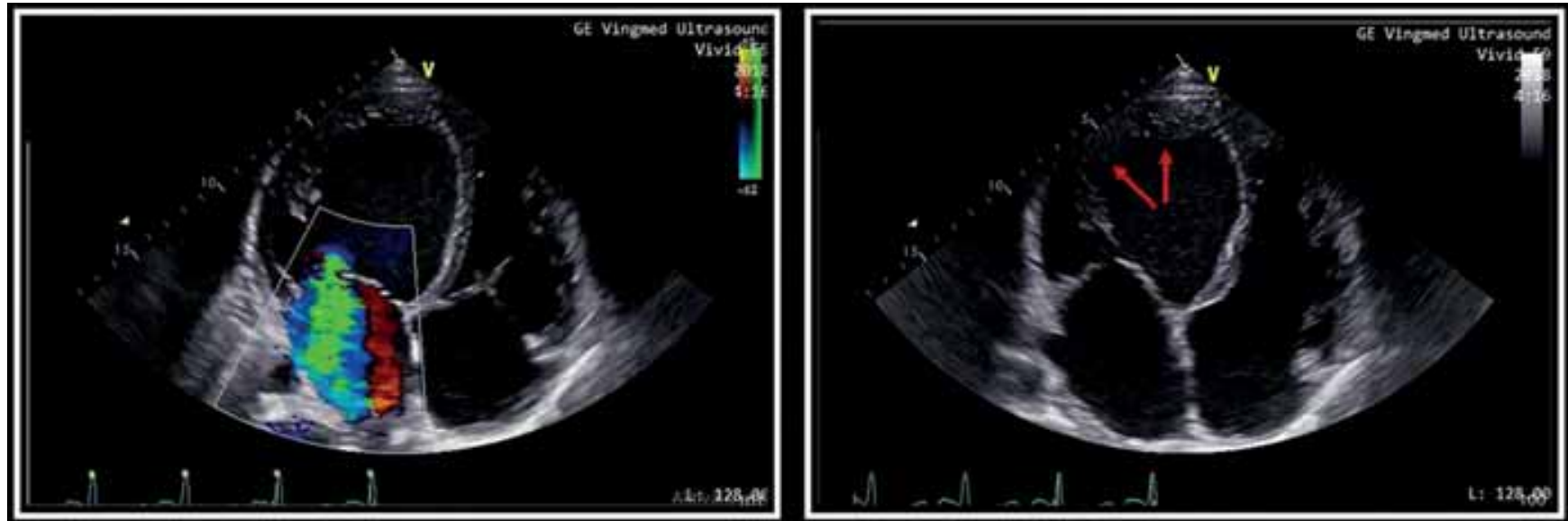

2. ÁBRA. Echokardiográfia (csúcsi négyüregi metszetek). Nagymértékben tágult szívüregek, jelentős mértékben csökkent szisztolés balkamra-funkció (EF 18-20\%), súlyos fokú funkcionális mitralis regurgitáció (bal oldali panel). A bal kamra csúcsában, a laterális fal mediális és csúcsi részénél non-compactatio merült fel (nyilak) (jobb oldali panel) 

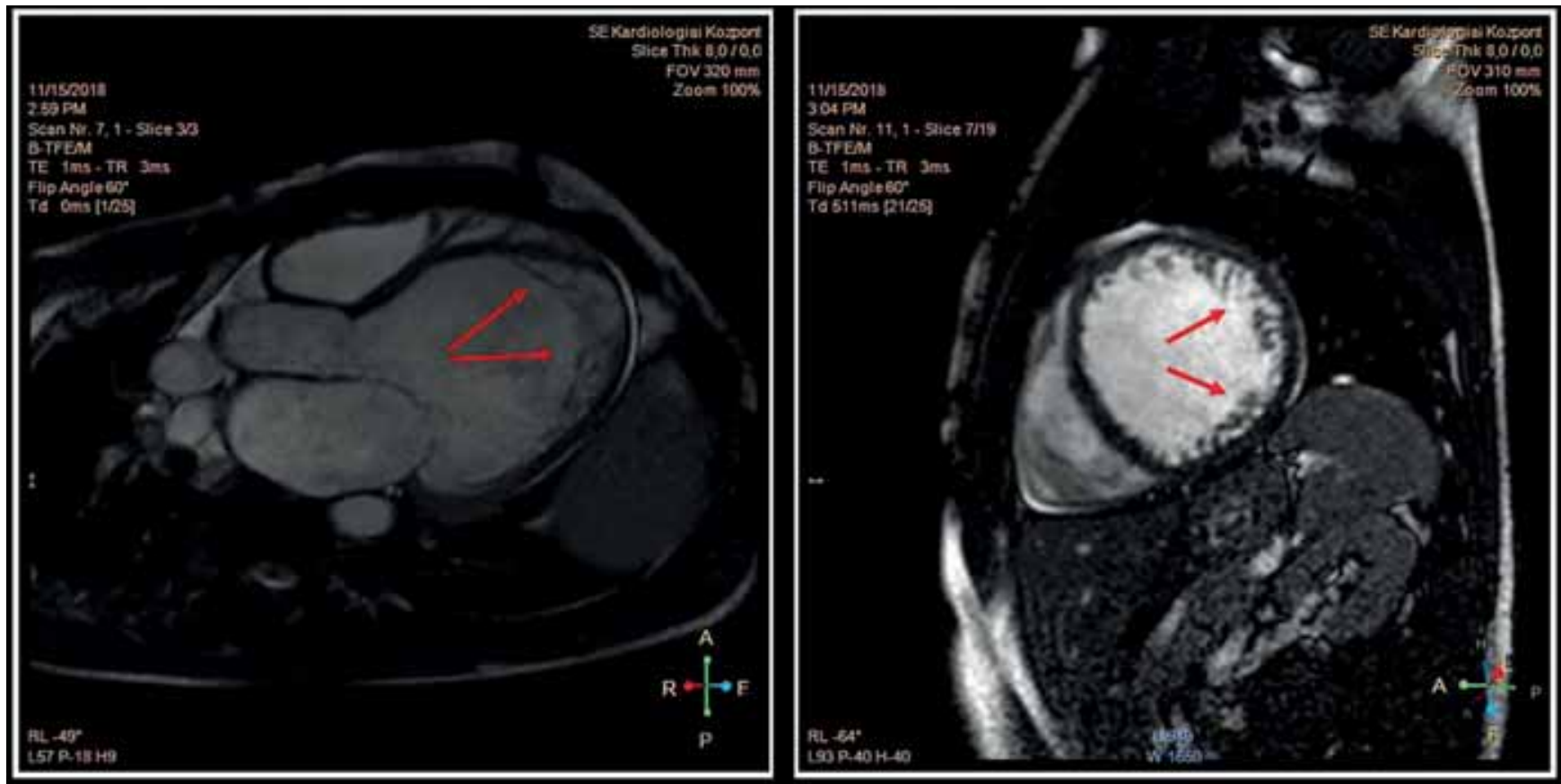

3. ÁBRA. A szív-MR megerősítette a non-compact cardiomyopathia (NCCMP) diagnózisát. A hossztengelyi (bal oldal) és rövidtengelyi (jobb oldal) síkokban készített BFFE (Balanced Fast Field Echo) felvételeken a csúcsi harmadban laterális dominanciával és a csúcsban fokozott bal kamrai trabekularizáció ábrázolódott (nyilak)

titrálása mellett a beteg terhelhetősége fokozatosan javult. NCCMP miatt orális antikoagulánst állítottunk be. Vashiány (alacsony ferritinszint és csökkent transzferrin-szaturáció) miatt iv. vas(III)-karboximaltózt adtunk. Az ACE-gátló mellett jelentkező száraz, életminőséget rontó ingerköhögés miatt ARNI-ra (sacubitril/valsartan) váltottunk, amely mellett a köhögés megszünt. A látott klinikai kép alapján szívtranszplantáció (HTX) irányú kivizsgálást kezdtünk, kontraindikációt képező eltérést nem találtunk. Holter EKG-n kb. 1700 kamrai extrasys-

1. TÁBLÁZAT. Szív-MR által leírt paraméterek: súlyosan csökkent bal kamrai ejekciós frakció, extrém mértékben emelkedett bal kamrai végdiasztolés és végszisztolés volumenek, sphericusan remodellált bal kamra, megtartott verővolumen, normál bal kamrai izomtömeg. Rövidítések: EDV: végdiasztolés volumen; ESV: végszisztolés volumen; SV: pulzusvolumen; EF: ejekciós frakció; CO: perctérfogat; mass ED: végdiasztolés izomtömeg; l: testfelszínre indexált paraméterek

\begin{tabular}{lcc} 
& Bal kamra & J obb kamra \\
\hline EDV $(\mathrm{ml})$ & 629 & 407 \\
\hline EDVI $\left(\mathrm{ml} / \mathrm{m}^{2}\right)$ & 289 & 186 \\
\hline ESV $(\mathrm{ml})$ & 506 & 335 \\
\hline ESVI $\left(\mathrm{ml} / \mathrm{m}^{2}\right)$ & 232 & 153 \\
\hline $\mathrm{SV}(\mathrm{ml})$ & 122 & 72 \\
\hline $\mathrm{SVI}\left(\mathrm{ml} / \mathrm{m}^{2}\right)$ & 56 & 33 \\
EF $(\%)$ & 19,5 & 18 \\
CO $(\mathrm{l})$ & 11,6 & 6,8 \\
\hline Mass ED $(\mathrm{g})$ & 175 & - \\
\hline Mass EDI $\left(\mathrm{g} / \mathrm{m}^{2}\right)$ & 80 & -
\end{tabular}

tole (VES), két alkalommal 4-5 tagból álló kamrai futam került rögzítésre, pitvarfibrilláció, non-sustained kamrai tachycardia, malignus kamrai ritmuszavar nem volt. Az újonnan felismert cardiomyopathia miatt - a jelenleg érvényben lévő szakmai ajánlás alapján - ICD-implantációt nem végeztünk, azonban egy klinikai tanulmány keretein belül a beteget 3 hónapra defibrillátor mellénynyel (wearable cardioverter defibrillator, WCD) láttuk el (4. ábra). A beteget 2018. november végén jó általános állapotban (NYHA II. funkcionális stádium) otthonába 
2. TÁBLÁZAT. A diagnózis felálításakor és a kontrollvizsgálat alkalmával végzett echokardiográfia (TTE) során mért paraméterek és $\mathrm{N}$-terminális pro B-típusú natriuretikus peptid (NT-proBNP) értékek. Rövidítések: BP: bal pitvar; BK: bal kamra; RVD1: basalis jobb kamrai átmérő; BK EF Simpson: bal kamrai ejekciós frakció Simpson-módszerrel meghatározva; LVOT VTI: bal kamra kifolyó traktusban mért sebesség idő integrál; dP/dt: bal kamrai nyomás emelkedésének paramétere izovolumetriás kontrakció idején; SV: verővolumen; MI: mitrális inszufficiencia, PISA EROA- PISA: (proximal isovelocity surface area) módszerrel számított effektív regurgitációs orificium area; Tl: tricuspidalis inszufficiencia; TAPSE: tricuspidalis anulus síkjának szisztolés előmozdulása; RVSP: jobb kamrai szisztolés nyomás; IVC: vena cava inferior

\begin{tabular}{|l|c|c|}
\hline BP $(\mathrm{mm})$ & 2018. október & 2019. február \\
\hline BK $(\mathrm{mm})$ & 53 & 51 \\
\hline RVD1 $(\mathrm{mm})$ & $77-88$ & $75-86$ \\
\hline BK EF Simpson (\%) & 58 & 48 \\
\hline LVOTVTI (m) & 15 & 30 \\
\hline dP/dt (Hgmm/s) & 0.06 & 0,18 \\
\hline SV (ml) & 872 & 860 \\
\hline MI (súlyossági fok) & 29 & 92 \\
\hline PISA EROA (cm²) & III & II-III \\
\hline Mitralis beáramlás & 0.18 & 0,14 \\
\hline TI (súlyossági fok) & Restriktív & Pseudonorm \\
\hline TAPSE (mm) & 20 & Jelzett \\
\hline RVSP (Hgmm) & $35+15$ & 25 \\
\hline IVC (mm) & 33 & $22+8$ \\
\hline NT-proBNP (ng/l) & 2436 & 22 \\
\hline
\end{tabular}

bocsájtottuk. Az egyenes ági hozzátartozók echokardiográfiás szürése negatív eredménnyel zárult.

Kontrollvizsgálat (2018. december) alkalmával a beteg terhelhetőségének további, jelentős javulásáról számolt be (naponta 2-5 km séta, 2-3 emelet lépcső), ritmuszavar nem jelentkezett, cardiopulmonalisan mindvégig kompenzált volt. Echokardiográfia a bal és jobb kamra szisztolés funkciójának javulását mutatta, a mitralis regurgitáció mértéke és a jobb kamrai nyomás csökkent, azonban a bal kamrai üregátmérők érdemben nem változtak (2. táblázat). A szívelégtelenség bázisterápia optimalizálását tovább folytattuk. 2019 januárjában vérnyomásmérés kapcsán észlelt alacsony pulzusszám hátterében Holter EKG-panaszokat nem okozó, de gyakori, monomorf, jobb kamrai kifolyó traktus (RVOT) kiindulású, többször bigemin formában jelentkező VES-eket igazolt (összütések 20\%-a). Az ismételt, változatlanul nagyszámú VES-eket mutató Holter EKG-vizsgálatok alapján elektrofiziológiai konzílium történt, a balkamra-funkció további csökkenésének megelőzése, illetve esetleges javulásának reményében a beteget ablációra előjegyezték. A látott klinikai és echokardiográfiás kép (extrém tág szívüregek, csökkent balkamra-funkció) alapján a WCD levételét követő- en a beteggel egyetértésben, primer prevenciós indikációval ICD-implantáció mellett döntöttünk, amely 2019 februárjában szövődménymentesen megtörtént. Azóta sokkleadás nem történt, a beteg terhelhetősége tovább javult (napi 5-8 km séta, 4-5 emelet lépcső), funkcionális stádium NYHA I. HTX irányú továbblépést a funkcionális állapot romlása vagy terápiarefrakter malignus kamrai ritmuszavar fellépése esetén tervezünk.

\section{Megbeszélés}

Az NCCMP elöször 1926-ban Grant (1) által került leírásra, mint egy heterogén miokardiális rendellenesség. A kórkép morfológiai alapja a kétrétegű myocardium (egy külső vékonyabb compact réteg [CM] és egy belső vaskosabb non-compact réteg [NCM]), amelynek sajátossága kóros trabekulák és a recesszusok jelenléte (2) (5. ábra). Patofiziológiai háttere továbbra is vita tárgyát képezi: nem egyértelmủ, hogy különálló entitásról van-e szó vagy egyéb szívbetegségek fenotípusos megjelenéséről. A jelenleg leginkább elfogadott elmélet szerint az NCCMP egy autoszomális domináns vagy X-kromoszómához kötött fejlődési rendellenesség (3), amely során a magzati szív fejlődésekor a szivacsos izomstruktúrából formálódó szívüregek fejlődése megakad, jellemzően non-compact réteg marad vissza (4). A diagnosztikus eljárások fejlődésével a morfológia megítélése egyre megbízhatóbb. Gyakran változó mértékủ non-compactatio kerül leírásra dilatatív, illetve a hipertrófiás cardiomyopathia esetén is. Az utóbbi kórképeknél a kontraktilis apparátust, illetve a citoszkeletont érintő mutációk átfedést mutatnak a non-compact cardiomyopathiában találtakkal (5). Ismert továbbá, hogy a versenysportolók között is fokozottabb a bal kamra trabekularizációja, amely felveti a nyomás- és volumenterhelés oki szerepét a kórkép kialakulásában (6).

Az NCCMP-esetek túlnyomó többségében a bal kamra laterális disztális és csúcsi területeket érintő betegségről van szó (5), de egyes variánsok a két kamra hasonló, vagy kizárólag a jobb kamra érintettségével járnak. Megjelenhet izoláltan, illetve kongenitális szívbetegségekhez társultan is. Egyes szerzők a non-compactatio gyakoriságát az átlagpopulációban 0,05\%-ra, míg szívelégtelen betegekben $4 \%$-ra teszik (7).

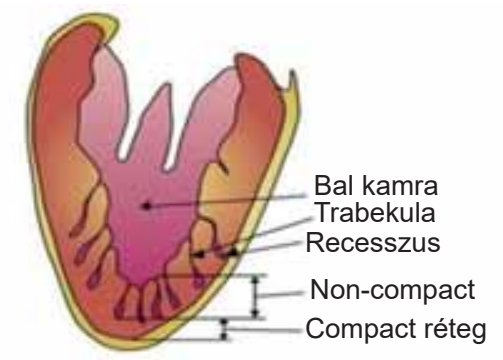

5. ÁBRA. Az NCCMP morfológiai megjelenése 
3. TÁBLÁZAT. NCCMP: képalkotó módszerek különböző kritériumrendszerei. Rövidítések: NCM: non-compact myocardium; CM: compact myocardium; PLAX: parasternális hosszú tengely; SAX: parasternális rövid tengely

\begin{tabular}{|c|c|c|c|c|c|c|c|}
\hline & $\begin{array}{l}\text { Chin és } \\
\text { mtsai (8) }\end{array}$ & $\begin{array}{l}\text { J enni és } \\
\text { mtsai (9) }\end{array}$ & $\begin{array}{l}\text { Stollberger } \\
\text { és mtsai (10) }\end{array}$ & $\begin{array}{l}\text { Paterick és } \\
\text { mtsai (11) }\end{array}$ & $\begin{array}{l}\text { Petersen és } \\
\text { mtsai (12) }\end{array}$ & $\begin{array}{l}\text { J aquier és } \\
\text { mtsai (13) }\end{array}$ & $\begin{array}{l}\text { Stacey és } \\
\text { mtsai (14) }\end{array}$ \\
\hline $\begin{array}{l}\text { Képalkotó } \\
\text { módszer }\end{array}$ & TTE & TTE & TTE & TTE & MR & MR & MR \\
\hline $\begin{array}{l}\text { Quantitatív } \\
\text { kritérium }\end{array}$ & $\begin{array}{l}\mathrm{CM} /(\mathrm{NCM}+\mathrm{CM}) \\
\leq 0,5\end{array}$ & $\mathrm{NCM} / \mathrm{CM}>2$ & $\geq 3$ trabecula & $\begin{array}{l}\mathrm{NCM} / \mathrm{CM} \\
>2\end{array}$ & $\begin{array}{l}\mathrm{NCM} / \mathrm{CM} \\
>2,3\end{array}$ & $\begin{array}{l}\text { LV NC töme- } \\
\text { ge }>20 \% \text { a } \\
\text { LV C tömege }\end{array}$ & $\begin{array}{l}\mathrm{NCM} / \mathrm{CM} \\
>2\end{array}$ \\
\hline $\begin{array}{l}\text { Qualitatív } \\
\text { kritérium }\end{array}$ & $\begin{array}{l}\text { Teljes falvastag- } \\
\text { ság (NCM+CM) } \\
\text { progresszív növe- } \\
\text { kedése a mitralis } \\
\text { billentyűtőll a csúcs } \\
\text { irányába; egyéb } \\
\text { szívanomália nincs } \\
\text { jelen }\end{array}$ & $\begin{array}{l}\text { Intertrabekulá- } \\
\text { ris recesszus } \\
\text { közlekedik a } \\
\text { bal kamrával } \\
\text { Color Dopplerrel } \\
\text { ábrázolva; egyéb } \\
\text { szívanomália } \\
\text { nincs jelen }\end{array}$ & $\begin{array}{l}\text { Intertrabekulá- } \\
\text { ris recesszus } \\
\text { közlekedik a } \\
\text { bal kamrával } \\
\text { Color Dopp- } \\
\text { lerrel ábrázolva }\end{array}$ & & $\begin{array}{l}2 \text { rétegü } \\
\text { myocardium }\end{array}$ & $\begin{array}{l}2 \text { rétegü } \\
\text { myocardium }\end{array}$ & $\begin{array}{l}2 \text { rétegü } \\
\text { myocardi- } \\
\text { um }\end{array}$ \\
\hline Nézet & $\begin{array}{l}\text { PLAX, csúcsi } 4 \\
\text { üregü }\end{array}$ & SAX & Számos & SAX & $\begin{array}{l}\text { Hosszú } \\
\text { tengely }\end{array}$ & $\begin{array}{l}\text { Rövid } \\
\text { tengely }\end{array}$ & $\begin{array}{l}\text { Rövid } \\
\text { tengely }\end{array}$ \\
\hline Szívciklus & Végdiasztolé & Végdiasztolé & $\begin{array}{l}\text { Nem } \\
\text { alkalmazandó }\end{array}$ & $\begin{array}{l}\text { Végdiasz- } \\
\text { tolé }\end{array}$ & Diasztolé & Végdiasztolé & $\begin{array}{l}\text { Végdiasz- } \\
\text { tolé }\end{array}$ \\
\hline $\begin{array}{l}\text { Mérések } \\
\text { anatómiai }\end{array}$ & $\begin{array}{l}\text { Bázis, papilláris } \\
\text { izom, apex }\end{array}$ & $\begin{array}{l}\text { Laterális kp., } \\
\text { inferior kp., apex }\end{array}$ & $\begin{array}{l}\text { Apex, lateralis } \\
\text { és inferior fal }\end{array}$ & & $\begin{array}{l}\text { Egész bal } \\
\text { kamra }\end{array}$ & $\begin{array}{l}\text { Egész bal } \\
\text { kamra }\end{array}$ & $\begin{array}{l}\text { Egész bal } \\
\text { kamra }\end{array}$ \\
\hline
\end{tabular}

A kórkép klinikai megjelenése igen változatos: a tünetmentestől a hirtelen szívhalált elszenvedő vagy a progresszív SzE-tünetek miatt szívtranszplantációt igénylő betegig terjedhet. A tünetek bármely életkorban megjelenhetnek és az esetek túlnyomó többségében a balkamra-diszfunkcióval hozhatók összefüggésbe. Felnőttkorban leggyakrabban szívelégtelenség (33-73\%), malignus kamrai ritmuszavar (6-63\%), pitvarfibrilláció (3,8-29\%), nem specifikus EKG-eltérések és szisztémás tromboembóliás események (21-38\%) jelentkezhetnek $(4,7)$.

Az NCCMP diagnózisának felálítása leggyakrabban a széles körben elérhető és könnyen kivitelezhető transztorakális echokardiográfia diagnosztikus kritériumrendszerein alapul. A szív-MR fejlődésével és mind szélesebb körben való elérhetőségének köszönhetően azonban egyre pontosabb képet kaphatunk a non-compactatio térbeli elhelyezkedéséről (3. táblázat). A jövőben ezen kritériumrendszerek még pontosabb kvantifikációja várható (15).

A kórkép kezelését tekintve nincs egységesen elfogadott szakmai álláspont. A terápia a szívelégtelenség kezelésére, illetve a várható szövődmények kivédésére irányul. Csökkent balkamra-funkció és pitvarfibrilláció esetén a szisztémás embolizáció megelőzése céljából orális antikoaguláns indítása szükséges. Felmerül ugyan a mély intertrabekuláris recesszusokban fellépő vérrögképződés lehetősége, mint önálló rizikótényező (16), azonban megtartott balkamra-funkció és pitvarfibrilláció hiánya esetén az embolizáció kockázata ismeretlen, az antikoaguláns szükségessége vitatott (17). A hirtelen szívhalál megelőzésére az NCCMP diagnózisa önmagában nem indokolja ICD implantációját, annak beültetése a jelenleg érvényben lévő ajánlások alapján történik. Végezetül rendkívül fontos az elsőfokú rokonok klinikai és genetikai szürése (18).

\section{Következtetések}

Az NCCMP egy ritka, potenciálisan magas morbiditással és mortalitással járó kórkép. Etiológiája jelenleg is vitatott, diagnózisa és kezelése az egységesen elfogadott irányelvek hiányában jelentős kihívás elé állítja a klinikust. A betegséggel kapcsolatos ismereteink bővítése céljából további patofiziológiai és klinikai vizsgálatok szükségesek.

\section{Irodalom}

1. Grant RT. An unusual anomaly of the coronary vessels in the malformed heart of a child. Heart 1926; 13: 273-283.

2. Pignatelli RH, McMahon CJ, Dreyer WJ, et al. Clinical characterization of left ventricular noncompaction in children: a relatively common form of cardiomyopathy. Circulation 2003; 108: 2672-2678. doi: 10.1161/01.CIR.0000100664.10777.B8

3. Sedmera D, Pexieder T, Vuillemin M, et al. Developmental patterning of the myocardium. Anat Rec 2000; 258: 319-337. doi: 10.1002/ (SICI)1097-0185(20000401)258:4<319::AID-AR1>3.0.CO;2-O

4. Morcos NP, Andersson ME, Adler ED. Left ventricular non-compaction: Current controversy and new insights. J Genet Syndr Gene Ther 2015, 6: 255.

5. Shemisa K, Li J, Tam M, Barcena J. Left ventricular non-compaction cardiomyopathy. Cardiovasc Diagn Ther 2013; 3(3): 170-175. doi: 10.3978/j.issn.2223-3652.2013.05.04

6. Abela M, D'Silva A. Left Ventricular Trabeculations in Athletes: Epiphenomenon or phenotype of disease? Curr Treat Options Cardiovasc Med 2018; 20 (12): 100. doi: 10.1007/s11936-018-0698-8 7. Towbin, Jeffrey $A$, et al. Left ventricular non-compaction cardi- 
omyopathy. The Lancet 2015; 386: 813-825. doi: 10.1016/S01406736(14)61282-4

8. Chin TK, Perloff JK, Williams RG, Jue K, Mohrmann R. Isolated noncompaction of left ventricular myocardium: a study of eight cases. Circulation 1990; 82: 507-513. doi: 10.1161/01.CIR.82.2.507 9. Jenni R, Oechslin E, Schneider J, Attenhofer Jost C, Kaufmann PA. Echocardiographic and pathoanatomical characteristics of isolated left ventricular non-compaction: a step towards classification as a distinct cardiomyopathy. Heart 2001; 86: 666-671. doi: 10.1136/ heart.86.6.666

10. Stöllberger C, Gerecke B, Finsterer J, Engberding R. Refinement of echocardiographic criteria for left ventricular noncompaction. In J Cardiol 2013; 165 (3):463-467. doi: 10.1016/j.ijcard.2011.08.845

11. Paterick TE, Umland MM, Jan MF, Ammar KA, Kramer C, Khandheria BK, et al. Left ventricular noncompaction: a 25-year odyssey. J Am Soc Echocardiogr 2012; 25 (4): 363-375. doi: 10.1016/j. echo.2011.12.023

12. Petersen SE, Selvanayagam JB, Wiesmann F, Robson MD, Francis JM, et al. Left ventricular non-compaction: insights from cardiovascular magnetic resonance imaging. J Am Coll Cardiol 2005; 46: 101-105. doi: 10.1016/j.jacc.2005.03.045

13. Jacquier A, Thuny F, Jop B, Giorgi R, Cohen F, et al. Measure- ment of trabeculated left ventricular mass using cardiac magnetic resonance imaging in the diagnosis of left ventricular non-compaction. Eur Heart J 2010; 31: 1098-1104. doi: 10.1093/eurheartj/ehp595 14. Stacey RB, Andersen MM, St Clair M, Hundley WG, Thohan V. Comparison of systolic and diastolic criteria for isolated LV non-compaction in CMR. JACC Cardiovasc Imaging 2013; 6: 931-940. doi: 10.1016/j.jcmg.2013.01.014

15. Hotta VT, Tendolo SC, Rodrigues ACT, et al. Limitations in the diagnosis of noncompaction cardiomyopathy by echocardiography. Arq Bras Cardiol 2017; 109 (5): 483-488. doi: 10.5935/abc. 20170152 16. Petersen SE, Timperley J, Neubauer S. Left ventricular thrombi in a patient with left ventricular non-compaction in visualisation of the rationale for anticoagulation. Heart 2005; 91: e4. doi: 10.1136/ hrt.2004.045971

17. Ikeda U, Minamisawa M, Koyama J. Isolated left ventricular non-compaction cardiomyopathy in adults, J Cardiol 2015; 65: 91 97. doi: 10.1016/j.jjcc.2014.10.005

18. Perry Elliott, Bert Andersson, Eloisa Arbustini, et al. Classification of the cardiomyopathies: a position statement from the european society of cardiology working group on myocardial and pericardial diseases. Eur Heart J 2008; 292: 270-276. doi: 10.1093/eurheartj/ ehm342 